\title{
Methylated Flavonols from Amomum koenigii J.F.Gmel. and Their Antimicrobial and Antioxidant Activities
}

\author{
Minh Giang Phan $\mathbb{D D}^{1}$ Thi Viet Huong Do $\mathbb{D}^{1},{ }^{1}$ and Quoc Binh Nguyen ${ }^{2}{ }^{2}$ \\ ${ }^{1}$ Faculty of Chemistry, VNU University of Science, Vietnam National University, Hanoi, 19 Le Thanh Tong Street, \\ Hanoi, Vietnam \\ ${ }^{2}$ Vietnam National Museum of Nature, Vietnam Academy of Science and Technology, 18 Hoang Quoc Viet Street, \\ Hanoi, Vietnam \\ Correspondence should be addressed to Minh Giang Phan; phanminhgiang@yahoo.com
}

Received 7 November 2019; Revised 21 December 2019; Accepted 9 January 2020; Published 18 February 2020

Academic Editor: Gary Lorigan

Copyright (C) 2020 Minh Giang Phan et al. This is an open access article distributed under the Creative Commons Attribution License, which permits unrestricted use, distribution, and reproduction in any medium, provided the original work is properly cited.

\begin{abstract}
Methylated flavonols form a special group with modulating biological activities in comparison with kaempferol and quercetin. The present study isolated ten compounds including two kaempferol methyl ethers: 5-hydroxy-3,7,4'-trimethoxyflavone (1), 3hydroxy-5,7,4'-trimethoxyflavone (6); four quercetin methyl ethers: retusin (5-hydroxy-3,7,3', $4^{\prime}$-tetramethoxyflavone) (4), 3,5dihydroxy-7,3', $4^{\prime}$-trimethoxyflavone (5), 3,4'-dihydroxy-5,7,3'-trimethoxyflavone (7), and 3,5,7,3', $4^{\prime}$-pentamethoxyflavone (9); $\beta$-sitosterol (2); 5-hydroxy-1-(4'-hydroxyphenyl)eicosan-3-one (3); $p$-hydroquinone (8); and vanillic acid (10) from the rhizomes and fruit of Amomum koenigii J.F.Gmel. (Zingiberaceae). Their structures were determined by MS, NMR, and X-ray spectroscopic techniques. Among the methylated flavonols, 1, 4-7, and $\mathbf{9}$ were isolated for the first time from the rhizomes, while 1, 4, and $\mathbf{5}$ were isolated from the fruit. Compounds 2, 3, 7, 8, and $\mathbf{1 0}$ were reported for the first time from the species. Three main methylated flavonols 1, 4, and $\mathbf{5}$ were quantitatively analyzed in the rhizomes of A. koenigii by RP-HPLC-DAD; their contents were determined to be $1.81 \%(\mathbf{1}), 1.38 \%(4)$, and $1.76 \%$ (5). The antimicrobial assay against Escherichia coli, Pseudomonas aeruginosa, Bacillus subtilis, Staphylococcus aureus, Aspergillus niger, Fusarium oxysporum, Candida albicans, and Saccharomyces cerevisiae and antioxidant DPPH scavenging test were performed for the isolated methylated flavonols.
\end{abstract}

\section{Introduction}

Amomum Roxb. is a large genus with about 250 species and belongs to Zingiberaceae. In recent years, 21 Amomum species have been recorded in Vietnam [1]. The chemistry of a few Amomum species from Vietnam has been studied [2-4]. The fruit of A. koenigii has been used as an aromatic stomachic in China, India, and Thailand $[5,6]$. A phytochemistry report on A. koenigii in China describes the isolation of eicosenones and methylated flavonols from the fruit of A. koenigii [5]. We investigated the occurrence of methylated flavonols in the fruit and rhizomes of $A$. koenigii from Vietnam (Figures S1 and S2) and isolated six methylated flavonols from the rhizomes for the first time. Their structures were analyzed by MS and 1D NMR spectroscopic techniques; the positions of methyl groups were determined by $2 \mathrm{D}$ NOESY and X-ray techniques. The contents of the main flavonoids in the rhizomes were analyzed by using RP-HPLC-DAD, and their antimicrobial and antioxidant activities were evaluated.

\section{Materials and Methods}

2.1. General Experimental Procedure. ESI-MS spectra were measured on a Thermo Fisher Scientific LTQ Orbitrap XL mass spectrometer in $\mathrm{CH}_{3} \mathrm{OH}$ solution. ${ }^{1} \mathrm{H}-\mathrm{NMR},{ }^{13} \mathrm{C}$ NMR, and DEPT spectra were recorded on a Bruker Avance $500 \mathrm{NMR}$ spectrometer at $500 \mathrm{MHz}$ for proton and $125 \mathrm{MHz}$ for carbon-13. Tetramethyl silane (TMS) was used as the NMR internal standard. Diaion HP-20 (Mitsubishi, Japan) and silica gel (Merck, Germany) of 40-63 and 15-40 $\mu \mathrm{m}$ were used for column chromatography (CC). Thin-layer chromatography (TLC) was performed on Merck precoated 
aluminum silica gel $60 \mathrm{~F}_{254}$ plates. Tryptone soya agar (TSB, Sigma-Aldrich, USA) and Sabouraud's dextrose agar (SDB, Sigma-Aldrich, USA) were used for the antimicrobial activity assay. Reagents and standard compounds used in the antioxidant DPPH scavenging assay were purchased from Sigma-Aldrich (USA).

2.2. Plant Material. The fresh fruit ( $3 \mathrm{~kg})$ and rhizomes $(16 \mathrm{~kg})$ of A. koenigii were collected in July 2016 from Chu Yang Sin National Park, Hoa Son Commune, Krong Bong District, Dak Lak Province, Vietnam (coordinates: from $12^{\circ} 14^{\prime} 16^{\prime \prime}$ north to $13^{\circ} 30^{\prime} 58^{\prime \prime}$ north and from $108^{\circ} 17^{\prime} 47^{\prime \prime}$ west to $108^{\circ} 34^{\prime} 48^{\prime \prime}$ west). The plant material was identified by Dr. Quoc Binh Nguyen, Vietnam National Museum of Nature, Vietnam Academy of Science and Technology, Hanoi, Vietnam. A voucher sample (No. AK-7-17) was deposited in the same museum.

\subsection{Extraction and Isolation}

2.3.1. The Rhizomes. The rhizomes were air-dried and then oven-dried at $40-50^{\circ} \mathrm{C}$. The dried material was ground into powder. The powder $(2.7 \mathrm{~kg})$ was macerated with $\mathrm{MeOH}$ at room temperature three times, each time for 7 days. The extracts were filtered and concentrated under reduced pressure to give the $\mathrm{MeOH}$ extract. The $\mathrm{MeOH}$ extract was suspended in water, and the water phase was extracted with $n$-hexane and dichloromethane. Evaporation of solvents under reduced pressure gave $n$-hexane- and dichloromethanesoluble fractions. The $n$-hexane- and dichloromethane-soluble fractions were combined based on their TLC similarities, and $20.2 \mathrm{~g}$ of the combined fraction was separated by CC over silica gel, eluting with $n$-hexane-acetone 19:1, 15:1, 9:1, 5:1, and $1: 1(\mathrm{v}: \mathrm{v})$ to give 11 fractions (Fr. 1-Fr. 11). Fr. 2 (0.83 g) was purified by CC over silica gel, eluting with $n$-hexane-EtOAc $49: 1,29: 1,19: 1,9: 1$, and $6: 1$ to give $1(112 \mathrm{mg})$ and 2 (20.1 mg). Frs. 4 and 5 were combined $(0.77 \mathrm{~g})$ and separated by CC over silica gel, eluting with $n$-hexane-acetone $20: 1,15$ : $1,12: 1,9: 1$, and $3: 1$ to yield $3(5 \mathrm{mg})$. Fr. 7 (1.73 g) was separated by CC over silica gel, eluting with $n$-hexane-acetone $20: 1,15: 1,9: 1,6: 1,3: 1$, and $1: 1$ to yield 1 (36.9 mg), $4(8.2 \mathrm{mg})$, and $5(25.4 \mathrm{mg})$. Frs. 8 and 9 were combined $(3.15 \mathrm{~g})$ and separated by CC over RP-18, eluting with $70 \%$, $80 \%$, and $90 \% \mathrm{MeOH}-\mathrm{H}_{2} \mathrm{O}$ and $\mathrm{MeOH}$. The fraction eluting with $\mathrm{MeOH}$ was separated by CC over silica gel, eluting with $n$ hexane-acetone $15: 1,12: 1,9: 1,6: 1$, and $3: 1$ to give 1 (5 mg). Fr. $10(2.41 \mathrm{~g})$ was separated by CC over RP-18, eluting with $70 \%, 80 \%$, and $90 \% \mathrm{MeOH}-\mathrm{H}_{2} \mathrm{O}$ and $\mathrm{MeOH}$. The fraction eluting with $70 \% \mathrm{MeOH}-\mathrm{H}_{2} \mathrm{O}(1.56 \mathrm{~g})$ was separated by repeated CC over silica gel, eluting with $n$-hexane-acetone $25: 1$, $20: 1,12: 1,9: 1,6: 1$, and $3: 1$ to give $4(2 \mathrm{mg})$ and $5(20 \mathrm{mg})$. Fractions eluting with $80 \%$ and $90 \% \quad \mathrm{MeOH}-\mathrm{H}_{2} \mathrm{O}$ were combined $(0.54 \mathrm{~g})$ and separated by CC over silica gel, eluting with $n$-hexane-EtOAc $12: 1,9: 1,6: 1,3: 1,1: 1$, and $1: 2$ to give 4 (5 mg), 6 (7.3 mg), 7 (30.2 mg), 8 (3 mg), and 9 (6 mg).

2.3.2. The Fruit. The fruit was washed, air-dried to remove surface water, and then crushed. The crushed fruit $(3 \mathrm{~kg})$ of
A. koenigii was extracted with methanol at room temperature five times, each for five days. The methanol extracts were combined and evaporated under reduced pressure. The residue was suspended in water and extracted with $n$-hexane and dichloromethane, and the organic phases were evaporated under reduced pressure to give $n$-hexane- and dichloromethane-soluble fractions. Half of the $n$-hexanesoluble fraction $(12.4 \mathrm{~g})$ was separated by CC over silica gel, eluting with $\mathrm{CH}_{2} \mathrm{Cl}_{2}-\mathrm{MeOH} 29: 1,19: 1,9: 1,6: 1,3: 1$, and $1: 1$ to give two fractions (Frs. 1 and 2). Fr. 1 ( $4.7 \mathrm{~g}$ ) was separated by CC over silica gel, eluting with $n$-hexaneEtOAc $29: 1,19: 1,9: 1,6: 1,3: 1$, and $1: 1$ to give 1 (15.0 mg), $4(6.0 \mathrm{mg}), 5(8.0 \mathrm{mg})$, and 8 (5 mg). The water-soluble fraction was passed through a column packed with Diaion HP-20, eluting with $20 \%$ and $60 \% \mathrm{MeOH}-\mathrm{H}_{2} \mathrm{O}$ and $\mathrm{MeOH}$. The fraction eluting with $20 \% \mathrm{MeOH}-\mathrm{H}_{2} \mathrm{O}(0.1 \mathrm{~g})$ was separated by $\mathrm{CC}$ over silica gel, eluting with $\mathrm{CH}_{2} \mathrm{Cl}_{2}$-EtOAc $15: 1,12: 1,9: 1,6: 1,3: 1$, and $1: 1$ to give $8(10 \mathrm{mg})$ and $\mathbf{1 0}$ (46 mg). The fraction eluting with $60 \% \mathrm{MeOH}-\mathrm{H}_{2} \mathrm{O}(0.2 \mathrm{~g})$ was separated by $\mathrm{CC}$ over silica gel, eluting with $\mathrm{CH}_{2} \mathrm{Cl}_{2}$ $\mathrm{MeOH} 30: 1,25: 1,15: 1,12: 1,9: 1,6: 1,3: 1$, and $1: 1$ to give 10 (34 mg).

2.4. RP-HPLC Analysis of Compounds 1, 4, and 5. Qualitative and quantitative HPLC analysis was performed with an HPLC-DAD Shimadzu SIL-20AC autosampler using a $5 \mu \mathrm{m}$ particle analytical RP-18 column $(4.6 \mathrm{~mm}$ $\times 250 \mathrm{~mm}$ ). The mobile phase was acetonitrile (HPLC grade)-deionized $\mathrm{H}_{2} \mathrm{O}$ gradient: $56 \%$ acetonitrile (0-5 min) and $100 \%$ acetonitrile $(5.1-15.5 \mathrm{~min})$. The flow rate was $1 \mathrm{~mL} / \mathrm{min}$. The injection volume was $20 \mu \mathrm{L}$. The column temperature was $30^{\circ} \mathrm{C}$. The HPLC conditions were optimized for the baseline, precision, accuracy, repeatability, LOD, and LOQ at the corresponding signal-to-noise ratios 3 and 10 (Table S1). A wavelength of $306 \mathrm{~nm}$ was selected for the detection of methyl flavonols. An accurate weight of the methanol rhizome extract $(34.7 \mathrm{mg}$ ) was dissolved in $1 \mathrm{~mL}$ $\mathrm{MeOH}$ of HPLC grade. The sample was passed through a silica gel solid-phase extraction (SPE) cartridge eluting with $\mathrm{MeOH}$ to remove impurities. The methanol solution was filtered through a $0.45 \mu \mathrm{m}$ Millipore membrane filter then analyzed directly by HPLC. The measurements were performed in triplicate to calculate the average values. A calibration curve showing the linear relationship between amounts of the standards injected ( $\mu \mathrm{g}, x$-axis) and the peak area ( $y$-axis) was constructed. The calibration standards were prepared by serial dilution of $1000 \mathrm{ppm}$ concentration stock solutions of $\mathbf{1}, \mathbf{4}$, and $\mathbf{5}$ (HPLC purity $\geq 95 \%$ ) (Figure S3).

2.5. X-Ray Crystallographic Analysis of Compounds 1 and 4. $\mathrm{X}$-ray diffraction data were collected on a Bruker APEX-II CCD diffractometer with Mo K $\alpha$ radiation $(\lambda=0.71073 \AA$ ). The procedures were done using the following tools: absorption correction: multi-scan, SADABS 2016/2 (Bruker, 2016/2); data collection: APEX3 (Bruker, 2017); cell refinement: SAINT (Bruker, 2001); data reduction: SAINT (Bruker, 2001); programs used to solve and refine structure: SHELXTL (Sheldrick, 2015); molecular graphics: SHELXTL 
(Sheldrick, 2015); and software used to prepare the material for publication: SHELXTL (Sheldrick, 2015). Reflections were collected at $100 \mathrm{~K}$.

2.6. Antimicrobial Activity Assay. The antimicrobial assay was performed in 96-well plates, and minimum inhibitory concentration (MIC) was determined as described by Vanden Berghe and Vlietinck [7]. The bacterial test organisms were cultured on tryptone soya agar (TSB, Sigma-Aldrich) and the test fungi on Sabouraud's dextrose agar (SDB, SigmaAldrich). The bacterial inocula were adjusted to yield a density of $1.5 \times 10^{8}$ colony forming units $(\mathrm{CFU} / \mathrm{mL})(0.5 \mathrm{McF}$ arland standard). The samples were dissolved in dimethylsulfoxide (DMSO) by vortexing and filtered through a $0.02 \mu \mathrm{m}$ microfilter to produce stock solutions. The wells were filled with $50 \mu \mathrm{L}$ stock solutions in DMSO and $50 \mu \mathrm{L}$ organism suspension. The positive controls were prepared in DMSO: ampicillin $(50 \mathrm{mM})$, tetracycline $(10 \mathrm{mM})$, and nystatin $(0.04 \mathrm{mM})$. MIC values of the positive controls were as follows: ampicillin $21.83 \mu \mathrm{g} / \mathrm{mL}$, tetracycline $6.87 \mu \mathrm{g} / \mathrm{mL}$, and nystatin $1.44 \mu \mathrm{g} / \mathrm{mL}$ (for yeasts) and $2.89 \mu \mathrm{g} / \mathrm{ml}$ (for fungi). The negative control was DMSO. The wells were allowed to diffuse for 24 -hour incubation at $37^{\circ} \mathrm{C}$ and 48 -hour incubation at $30^{\circ} \mathrm{C}$ for bacteria and fungi, respectively. The results were positive when no growth was observed $(\mathrm{CFU}<5)$. MIC was determined by using serial dilution of the stock solutions. MIC is defined as the lowest concentration of the compounds that showed no growth compared with growth in control (DMSO) wells. All determinations were performed in triplicate.

2.7. DPPH Free Radical-Scavenging Assay. Approximately, $3 \mathrm{~mL}$ of $0.1 \mathrm{mM}$ solution of 1,1-diphenyl-2-picrylhydrazyl (DPPH) radical in EtOH 96\% was each added into six series of prepared concentrations of sample solutions $(1 \mathrm{~mL}$ in DMSO). The test was performed in triplicate. The solution was mixed vigorously and left to stand at room temperature for $30 \mathrm{~min}$ in the dark after which its absorbance was measured spectrophotometrically at $515 \mathrm{~nm}$ using an ultraviolet spectrophotometer. DMSO was used as the blank and negative control ( $1 \mathrm{~mL}$ DMSO mixed with $3 \mathrm{~mL}$ DPPH), and quercetin was used as the standard. The concentration of the sample required to inhibit $50 \%$ of DPPH free radicals is denoted as $\mathrm{SC}_{50}$, and the value was determined using TableCurve AISN Software (Jandel Scientific) based on the calculated values of the DPPH scavenging activity (\%) of the sample. DPPH scavenging activity (\%) was calculated with the following formula: scavenging capacity (SC) $(\%)=$ $100-(A 1-A 0) / A_{\text {control }} \times 100$, where $A 0$ is the absorbance of the blank (sample in DMSO), $A_{\text {control }}$ is the absorbance of the negative control, while $A 1$ is the absorbance in the presence of the sample [8].

\section{Results and Discussion}

3.1. Structure Elucidation of Compounds 1-10. 5-Hydroxy-3,7,4'-trimethoxyflavone (1) $[5,9], \beta$-sitosterol (2) [10], 5-hydroxy-1-(4'-hydroxyphenyl)eicosan-3-one (3)
[11], retusin (5-hydroxy-3,7, $3^{\prime}, 4^{\prime}$-tetramethoxyflavone) (4) $[5,12], 3,5$-dihydroxy-7, $3^{\prime}, 4^{\prime}$-trimethoxyflavone $(5)[5,13]$, 3-hydroxy-5,7,4' -trimethoxyflavone (6) [5], 3,4' -dihydroxy5,7,3'-trimethoxyflavone (7), p-hydroquinone (8) [14], $3,5,7,3^{\prime}, 4^{\prime}$-pentamethoxyflavone $(9)[5,15]$, and vanillic acid (10) $[16,17]$ were isolated from the rhizomes and fruit of $A$. koenigii (Figure 1). The methylated flavonols include kaempferol methyl ethers $\mathbf{1}$ and $\mathbf{6}$ and quercetin methyl ethers 4, 5, 7, and 9. Among the methylated flavonols, compounds 1, 4-7, and 9 were isolated from the rhizomes and compounds 1, 4, and $\mathbf{5}$ were isolated from the fruit. Compounds 2, 3, 7, 8, and 10 were reported for the first time from the species. The structures of the compounds were identified using MS and NMR spectroscopy and by comparison of their spectroscopic data with literature values. 2D NOESY and X-ray crystallographic techniques were used to determine the positions of methyl groups in compounds $\mathbf{1}, \mathbf{4}$, 6 , and 7 .

\subsection{X-Ray Crystallographic Analysis of Methylated Flavonols 1} and 4. Single crystals of 1 (crystal size $0.43 \times 0.23 \times 0.12 \mathrm{~mm}$ ) and 4 (crystal size $0.37 \times 0.07 \times 0.04 \mathrm{~mm}$ ) were prepared by recrystallization. We confirmed the locations of the methyl substituents (A-ring 5,7-substitution and B-ring 1,4- and 1,3,4-substitution) in $\mathbf{1}$ and $\mathbf{4}$ by X-ray crystallographic analysis. The unit cell of $\mathbf{1}$ was determined to be the triclinic crystal system, $\mathrm{P}-1$ space group with $Z=2$ and molecular formula $\mathrm{C}_{18} \mathrm{H}_{16} \mathrm{O}_{6}$ (Figure S4; Table S2). The molecule is nonplanar with the dihedral angle between the benzopyranone ring and the 4-substituted phenyl ring of $28.971(6)^{\circ}$. In the crystal, molecules of $\mathbf{1}$ are linked by weak intermolecular $\mathrm{C}-\mathrm{H}$... O hydrogen bonds forming ribbons lying parallel to (100) (Figure S5; Table S3).

The unit cell of 4 was determined to be orthorhombic crystal system, $\mathrm{Pbca}$ space group with $Z=47$ and molecular formula $\mathrm{C}_{19} \mathrm{H}_{18} \mathrm{O}_{7}$ (Figure S6; Table S4). Excluding the methyl moieties of the substituted methoxy groups, the molecule of $\mathbf{4}$ is essentially planar with non- $\mathrm{H}$ atoms exhibiting mean and maximum deviations from coplanarity of 0.0808 and $0.0896 \AA$, respectively. In the crystal, molecules are linked by weak intermolecular $\mathrm{C}-\mathrm{H}$. . . O hydrogen bonds forming ribbons lying parallel to (100) (Figure S7; Table S5).

3.3. HPLC Analysis of Compounds 1, 4, and 5. Previously, compounds 1, 4, 3,7-dihydroxy-5,4'-dimethoxyflavone, and 3,7-dihydroxy-5, $3^{\prime}, 4^{\prime}$-trimethoxyflavone were analyzed in the seeds and pericarps of $A$. koenigii collected from Guangxi Province and Yunnan Province of China [6]. A typical analytical HPLC chromatogram of the rhizome methanol extract is shown in Figure S8. Compounds 1, 4, and 3,5dihydroxy-7, $3^{\prime}, 4^{\prime}$-trimethoxyflavone (5) showed three main peaks in the HPLC chromatogram of the rhizome $\mathrm{MeOH}$ extract of $A$. koenigii from Vietnam. The retention times of $\mathbf{1}$, 4, and 5 were $12.6,11.9$, and $10.3 \mathrm{~min}$, respectively. According to the HPLC quantification, the flavonoids were present in the rhizomes of $A$. koenigii in dry quantities of $1.81 \%(1), 1.38 \%(4)$, and $1.76 \%(5)$. The content of the major compound 4 (retusin) was almost $0.5 \%$ in the seeds [6] 
<smiles>CCC(CC[C@@H](C)C1CCC2C3CC=C4CC(O)CCC4(C)C3CCC21C)C(C)C</smiles><smiles>CCCCCCCCCCC(O)CC(=O)CCc1ccc(O)cc1</smiles>

3<smiles>COc1cc(O)c2c(=O)c(OC)c(-c3ccc(OC)c(OC)c3)oc2c1</smiles>

4<smiles>COc1cc(OC)c2c(=O)c(O)c(-c3ccc(O)c(OC)c3)oc2c1</smiles>

7<smiles>COc1cc(O)c2c(=O)c(O)c(-c3ccc(OC)c(OC)c3)oc2c1</smiles>

5<smiles>COc1ccc(-c2oc3cc(OC)cc(OC)c3c(=O)c2O)cc1</smiles>

6<smiles>Oc1ccc(O)cc1</smiles><smiles>COc1cc(OC)c2c(=O)c(OC)c(-c3ccc(OC)c(OC)c3)oc2c1</smiles>

9<smiles>COc1cc(C(=O)O)ccc1O</smiles>

10

Figure 1: Structures of compounds 1-10.

which is much lower than its content in the rhizomes in the present study.

3.4. Antimicrobial Activity of Compounds 1 and 4-7. Five methylated flavonols 1 and 4-7 were tested for their antibacterial and antifungal activity as described by Vanden Berghe and Vlietinck [7]. The microorganisms used included Escherichia coli (ATCC 25922), Pseudomonas aeruginosa (ATCC 25923), Bacillus subtilis (ATCC 27212), Staphylococcus aureus (ATCC 12222), Aspergillus niger (439), Fusarium oxysporum (M42), Candida albicans (ATCC 7754), and Saccharomyces cerevisiae (SH 20). The samples were tested for their antimicrobial activity, and the active samples underwent serial 2-fold dilutions to determine MIC values. The MIC is defined as the lowest concentration of compounds that inhibits any visible growth of microorganisms after incubation. Compounds were tested at the concentrations of $100 \mu \mathrm{g} / \mathrm{mL}(\mathbf{1}, \mathbf{4}$, and 5) and $50 \mu \mathrm{g} / \mathrm{mL}(\mathbf{6}$ and 7 ); only 4 showed potent activity against $A$. niger with an MIC value of $100 \mu \mathrm{g} / \mathrm{mL}$ (Table 1). Quercetin is a broadrange antibacterial compound; it is active against $S$. aureus (MIC $100 \mu \mathrm{g} / \mathrm{mL}$ ), P. aeruginosa (MIC $100 \mu \mathrm{g} / \mathrm{mL}$ ) [18], and E. coli $\left(\mathrm{MIC}_{50} 35.76 \mu \mathrm{g} / \mathrm{mL}\right)$ [19]. In accordance with our results, high levels of methylation in 4,5 , and 7 decreased the antibacterial activity, and the presence of the hydroxyl groups at $\mathrm{C}-3^{\prime}$ and $\mathrm{C}-4^{\prime}$ in the catechol moiety of the flavonoid $\mathrm{B}$ ring was important for the activity, while the free hydroxyl groups at C-3, C-5, and C-4' were not critical. Kaempferol is much less active than quercetin, showing MIC values against $S$. aureus and B. cereus of $500 \mu \mathrm{g} / \mathrm{mL}$, but it is strongly active against $E$. coli $\left(\mathrm{MIC}_{50} 25 \mu \mathrm{g} / \mathrm{mL}\right)$ [20]. Çitoğlu et al. noted that the presence of free hydroxyl groups at C-5 and C-4' was not significant for strong antibacterial activity of kaempferol methyl ethers [21]. No activity was observed for 6 showing that the free hydroxyl group at C-3 was not critical for strong antibacterial activity.

3.5. Antioxidant Activity of Compounds 4, 5, and 7. The antioxidant activity of three methylated quercetins 4,5 , and 7 was evaluated based on the scavenging activity test against DPPH. Compounds 4, 5, and 7 were selected because quercetin with its catechol (3,4-dihydroxyphenyl) structure in the flavonoid B ring is a much stronger antioxidant than kaempferol [22]. The samples were dissolved in DMSO, and DPPH was added to ethanol 96\%. The absorbance of DPPH was read at $\lambda=515 \mathrm{~nm}$. The tests were triplicated, and the results were averaged $(p<0.05)$. As a result, compounds 4 $(30.03 \%, 100 \mu \mathrm{g} / \mathrm{mL})$ and $5(14.20 \%, 100 \mu \mathrm{g} / \mathrm{mL})$ showed a lower scavenging activity in comparison with that of quercetin $(72.78 \%, 44 \mu \mathrm{g} / \mathrm{mL}$ ) (Table 2 ). The results provided evidence for the importance of the 3,4-dihydroxyphenyl moiety of the flavonoid B ring in the scavenging activity of quercetin derivatives [22]. No activity was observed for 9 having no free hydroxyl group implying that the C-ring $\alpha$, 
TABLE 1: Results of the antimicrobial activity test.

\begin{tabular}{|c|c|c|c|c|c|c|c|c|c|c|}
\hline \multirow{2}{*}{ No. } & \multirow{2}{*}{ Sample } & \multirow{2}{*}{ Concentration $(\mu \mathrm{g} / \mathrm{mL})$} & \multicolumn{8}{|c|}{ Minimum inhibitory concentration (MIC, $\mu \mathrm{g} / \mathrm{mL}$ ) } \\
\hline & & & E. coli & P. aeruginosa & B. subtilis & S. aureus & A. niger & F. oxysporum & S. cerevisiae & C. albicans \\
\hline 1 & 1 & 100 & - & - & - & - & - & - & - & - \\
\hline 2 & 4 & 100 & - & - & - & - & 100 & - & - & - \\
\hline 3 & 5 & 100 & - & - & - & - & - & - & - & - \\
\hline 4 & 6 & 50 & - & - & - & - & - & - & - & - \\
\hline 5 & 7 & 50 & - & - & - & - & - & - & - & - \\
\hline
\end{tabular}

-: not active.

TABLE 2: Results of the antioxidant activity test.

\begin{tabular}{lcccc}
\hline No. & Sample & Concentration $(\mu \mathrm{g} / \mathrm{mL})$ & Scavenging capacity $(\mathrm{SC}, \%)$ & $\mathrm{SC}_{50}(\mu \mathrm{g} / \mathrm{mL})$ \\
\hline 1 & DPPH/EtOH $(5 \mathrm{mM}$ ascorbic acid) & 15 & $76.65 \pm 0.27$ & 0 \\
2 & DPPH/EtOH + DMSO & - & $72.78 \pm 0.30$ & 12.67 \\
3 & Quercetin & 100 & $30.03 \pm 1.52$ & - \\
4 & $\mathbf{4}$ & 100 & $14.20 \pm 1.12$ & - \\
5 & $\mathbf{5}$ & 50 & $42.61 \pm 0.36$ & - \\
6 & 7 & 50 & 0.00 & - \\
7 & $\mathbf{9}$ & & 46.86 \\
\hline
\end{tabular}

-: not calculated.

$\beta$-unsaturated carbonyl alone is not a requisite for the scavenging activity without the free hydroxyl group at C-3. A slight increase in the scavenging activity of $7(42.61 \%, 50 \mu \mathrm{g} /$ $\mathrm{mL}$ ) in comparison with those of $\mathbf{4}$ and $\mathbf{5}$ was related to the presence of a free hydroxyl group at C- $4^{\prime}$ since the 5hydroxyl group was already blocked and the SC value of $\mathbf{5}$ with a free hydroxyl group at C-3 was relatively low.

\section{Conclusions}

Two kaempferol methyl ethers: 5-hydroxy-3,7,4'-trimethoxyflavone (1) and 3-hydroxy-5,7,4'-trimethoxyflavone (6), and four methylated quercetin methyl ethers: retusin (5-hydroxy-3,7,3', $4^{\prime}$-tetramethoxyflavone) (4), 3,5-dihydroxy-7,3', $4^{\prime}$-trimethoxyflavone (5), 3,4' -dihydroxy-5,7,3' trimethoxyflavone (7), and $3,5,7,3^{\prime}, 4^{\prime}$-pentamethoxyflavone (9), were isolated for the first time from the rhizomes of A. koenigii from Vietnam. Three methylated compounds 1, 4, and 5 were isolated from the fruit. The nonflavonoid compounds $\beta$-sitosterol (2), 5-hydroxy-1( $4^{\prime}$-hydroxyphenyl)eicosan-3-one (3), p-hydroquinone (8), and vanillic acid (10) were isolated for the first time from $A$. koenigii. Quantitative HPLC analysis revealed $1.81 \%$ of $\mathbf{1}$, $1.38 \%$ of 4 , and $1.76 \%$ of 5 in dry rhizomes. In the antimicrobial activity test, except for the potent activity of $\mathbf{4}$ against $A$. niger with the MIC value of $100 \mu \mathrm{g} / \mathrm{mL}$, compounds 1,4 , and 5 were not active at $100 \mu \mathrm{g} / \mathrm{mL}$ and 6 and 7 were not active at $50 \mu \mathrm{g} / \mathrm{mL}$. Weak DPPH scavenging activity of three quercetin methyl ethers 4 (30.03\%), 5 (14.20\%), and 7 (42.61\%) was observed at $100 \mu \mathrm{g} / \mathrm{mL}$ (4 and 5) or $50 \mu \mathrm{g} / \mathrm{mL}$ (7) concentration.

\section{Data Availability}

The data used to support the findings of this study are available from the corresponding author upon request.

\section{Conflicts of Interest}

The authors declare that there are no conflicts of interest regarding the publication of this paper.

\section{Acknowledgments}

This research was funded by the Vietnam National Foundation for Science and Technology Development (NAFOSTED) under grant no. 104.01-2017.41.

\section{Supplementary Materials}

Figure S1: Amomum koenigii J.F.Gmel. Figure S2: the fruit of Amomum koenigii J.F.Gmel. Figure S3: standard calibration curves of 1, 4, and 5. Figure S4: molecular conformation of 1 (displacement ellipsoids are drawn at the 50\% probability level). Figure S5: a view along the a-axis of the crystal packing of $\mathbf{1}$. The hydrogen bonds are shown as dashed lines (see Table S1 for details). Figure S6: molecular conformation of 4 (displacement ellipsoids are drawn at the 50\% probability level). Figure S7: a view along the a-axis of the crystal packing of 4. The hydrogen bonds are shown as dashed lines (see Table 2 for details). Figure S8: HPLC chromatogram of the rhizome methanol extract. Figure S9: ${ }^{1} \mathrm{H}-\mathrm{NMR}$ of 5 hydroxy-3,7,4'-trimethoxyflavone (1). Figure S10: ${ }^{1} \mathrm{H}-\mathrm{NMR}$ and ${ }^{13} \mathrm{C}$-NMR of 5-hydroxy-1-(4'-hydroxyphenyl)eicosan3-one (3). Figure S11: ${ }^{1} \mathrm{H}-\mathrm{NMR}$ of 5 -hydroxy-3,7,3',4'-tetramethoxyflavone (4). Figure S12: ${ }^{1} \mathrm{H}$-NMR of 3,5-dihydroxy-7,3 $3^{\prime}, 4^{\prime}$-trimethoxyflavone (5). Figure S13: ${ }^{1} \mathrm{H}-\mathrm{NMR}$ and NOESY of 3-hydroxy-5,7,4'-trimethoxyflavone (6). Figure S14: ${ }^{1} \mathrm{H}-\mathrm{NMR}$ and NOESY of $3,4^{\prime}$-dihydroxy-5,7,3' trimethoxyflavone (7). Figure S15: ${ }^{1} \mathrm{H}-\mathrm{NMR}$ and ${ }^{13} \mathrm{C}-\mathrm{NMR}$ of $p$-hydroquinone (8). Figure S16: ${ }^{1} \mathrm{H}$-NMR and NOESY of $3,5,7,3^{\prime}, 4^{\prime}$-pentamethoxyflavone (9). Figure S17: ${ }^{1} \mathrm{H}-\mathrm{NMR}$ and ${ }^{13} \mathrm{C}-\mathrm{NMR}$ of vanillic acid (10). Table S1: calibration 
equations, LODs, and LOQs of 1, 4, and 5. Table S2: crystallographic data and structural refinement of $\mathbf{1}$. Table S3: hydrogen bond geometry $(\AA)$ of 1 . Table S4: crystallographic data and structural refinement of 4. Table S5: hydrogen bond geometry $(\AA)$ of 4. (Supplementary Materials)

\section{References}

[1] T. H. Le, T. B. Tran, and Q. B. Nguyen, "Utilization pattern of genera Alpinia and Amomum (zingiberaceae) in North Central Vietnam," in Proceedings of the 6th National Scientific Conference of Ecology and Biological Resources, pp. 1150-1154, Hanoi, Vietnam, 2015.

[2] P. M. Giang, P. T. Son, K. Matsunami, and H. Otsuka, "New diarylheptanoids from Amomum muricarpum Elmer," Chemical and Pharmaceutical Bullelin, vol. 54, no. 1, pp. 139-140, 2006.

[3] P. M. Giang, P. T. Son, K. Matsunami, and H. Otsuka, "One new and several minor diarylheptanoids from Amomum muricarpum," Natural Product Research, vol. 26, no. 13, pp. 1195-1200, 2012.

[4] P. M. Giang, L. A. Tu, V. M. Trang et al., "Absolute configuration of a new phenethylcyclohexanetriol and a new natural bibenzyl from Amomum celsum," Natural Product Communications, vol. 14, no. 5, pp. 1-6, 2019.

[5] H. Dong, Y.-L. Gou, S.-G. Cao et al., "Eicosenones and methylated flavonols from Amomum koenigii," Phytochemistry, vol. 50, no. 5, pp. 899-902, 1999.

[6] C. F. Qiao, Q. B. Han, J. Z. Song, H. Yiu, and H. X. Xu, "Simultaneous HPLC-DAD analysis of four methylated flavonols in Amomum koenigii," Acta Chromatographica, vol. 19, no. 19, pp. 217-226, 2007.

[7] D. A. Vanden Berghe and A. J. Vlietinck, "Screening methods for antibacterial and antiviral agents from higher plants," in Methods in Plant Biochemistry, K. Hostettmann, P. M. Dey, and J. B. Harborne, Eds., vol. 6, pp. 47-69, Academic Press, London, UK, 1991.

[8] S. Gorinstein, O. Martin, E. Katrich et al., "Comparison of the contents of the main biochemical compounds and the antioxidant activity of some Spanish olive oils as determined by four different radical scavenging tests," Journal of Nutritional Biochemistry, vol. 14, no. 3, pp. 154-159, 2003.

[9] I. Macedo, J. H. da Silva, P. T. da Silva et al., "Structural and microbiological characterization of 5-hydroxy-3,7,4'-trimethoxyflavone: a flavonoid isolated from Vitex gardneriana Schauer leaves," Microbial Drug Resistance, vol. 25, no. 3, pp. 434-438, 2019.

[10] L. J. Goad and T. Akihisa, Analysis of Sterols, Blackie Academic \& Professional, London, UK, 1997.

[11] A. A. Salim, B. N. Su, H. B. Chai et al., "Dioxadispiroketal compounds and a potential acyclic precursor from Amomum aculeatum," Tetrahedron Letters, vol. 48, no. 10, pp. 1849-1853, 2007.

[12] M. Al-Oqail, W. H. B. Hassan, M. S. Ahmad, and A. J. AlRehaily, "Phytochemical and biological studies of Solanum schimperianum Hochst," Saudi Pharmaceutical Journal, vol. 20, no. 4, pp. 371-379, 2012.

[13] Q. H. Trieu, T. T. D. Pham, T. T. H. Do et al., "Preliminary study on chemical constituents of the leaves of Goniothalamus gracilipes Ban (Annonaceae)," Hung Vuong University Journal of Science and Technology, vol. 1, pp. 39-41, 2015.

[14] R. Erenler, O. Sen, H. Aksit et al., "Isolation and identification of chemical constituents from Origanum majorana and investigation of antiproliferative and antioxidant activities,"
Journal of Science of Food and Agriculture, vol. 96, no. 3, pp. 822-836, 2016.

[15] L. Chen, T. He, Y. Han, J. S. Sheng, S. Jin, and M. W. Jin, "Pentamethylquercetin improves adiponectin expression in differentiated 3T3-L1 cells via a mechanism that implicates PPAR $\gamma$ together with TNF- $\alpha$ and IL-6," Molecules, vol. 16, no. 7, pp. 5754-5768, 2011.

[16] G. Y. Chen, C. Y. Dai, T. S. Wang, C. W. Jiang, C. R. Han, and X. P. Song, "A new flavonol from the stem bark of Premna fulva," Arkivoc, vol. 2010, no. 2, pp. 179-185, 2010.

[17] A. Venditti, C. Frezza, F. Sciubba et al., "Volatile components, polar constituents and biological activity of tansy daisy (Tanacetum macrophyllum (Waldst. et Kit.) Schultz Bip.)," Industrial Crops and Products, vol. 118, pp. 225-235, 2018.

[18] R. Narendra Jaisinghani, "Antibacterial properties of quercetin," Microbiological Research, vol. 8, no. 1, 2017.

[19] T. Wu, M. He, X. Zang et al., "A structure-activity relationship study of flavonoids as inhibitors of E. coli by membrane interaction effect," Biochimica et Biophysica Acta (BBA)Biomembranes, vol. 1828, no. 11, pp. 2751-2756, 2013.

[20] Y. Sivasothy, S. F. Sulaiman, K. L. Ooi, H. Ibrahim, and K. Awang, "Antioxidant and antibacterial activities of flavonoids and curcuminoids from Zingiber spectabile Griff," Food Control, vol. 30, no. 2, pp. 714-720, 2013.

[21] G. S. Çitoğlu, B. Sever, S. Antus, S. Baitz-Gács, and N. Altanlar, "Antifungal flavonoids from Ballota glandulosissima," Pharmaceutical Biology, vol. 41, no. 7, pp. 483-486, 2003.

[22] P.-G. Pietta, "Flavonoids as antioxidants," Journal of Natural Products, vol. 63, no. 7, pp. 1035-1042, 2000. 